Article

\title{
Enzymatic Digestion of Calf Fleshing Meat By-Products: Antioxidant and Anti-Tyrosinase Activity of Protein Hydrolysates, and Identification of Fatty Acids
}

\author{
Tullia Tedeschi ${ }^{1, *}$, Cecilia Anzani ${ }^{1}$, Maura Ferri ${ }^{2,3}{ }^{\mathbb{D}}$, Silvia Marzocchi ${ }^{4}\left(\mathbb{D}\right.$, Maria Fiorenza Caboni ${ }^{4}$, \\ Stefania Monari ${ }^{2}$ and Annalisa Tassoni ${ }^{2, *(D)}$
}

1 Department of Food and Drug, University of Parma, Parco Area Delle Scienze 49/a, 43124 Parma, Italy; anzani.cecilia@gmail.com

2 Department of Biological, Geological, Environmental Science, University of Bologna, Via Irnerio 42, 40126 Bologna, Italy; maura.ferri@unibo.it (M.F.); stefania.monari2@unibo.it (S.M.)

3 Department of Civil, Chemical, Environmental and Materials Engineering, University of Bologna, Via Terracini 28, 40131 Bologna, Italy

4 Department of Agricultural and Food Sciences and Technologies, University of Bologna, Piazza Goidanich 60, 47521 Cesena, Italy; silvia.marzocchi4@unibo.it (S.M.); maria.caboni@unibo.it (M.F.C.)

* Correspondence: tullia.tedeschi@unipr.it (T.T.); annalisa.tassoni2@unibo.it (A.T.); Tel: +39-0521-905406 (T.T.); +39-051-2091278 (A.T.)

Citation: Tedeschi, T.; Anzani, C.; Ferri, M.; Marzocchi, S.; Caboni, M.F.; Monari, S.; Tassoni, A. Enzymatic Digestion of Calf Fleshing Meat By-Products: Antioxidant and Anti-Tyrosinase Activity of Protein Hydrolysates, and Identification of Fatty Acids. Foods 2021, 10, 755. https://doi.org/10.3390/foods 10040755

Academic Editors: Remedios Yáñez and Beatriz Gullon

Received: 23 February 2021

Accepted: 30 March 2021

Published: 2 April 2021

Publisher's Note: MDPI stays neutral with regard to jurisdictional claims in published maps and institutional affiliations.

Copyright: (C) 2021 by the authors Licensee MDPI, Basel, Switzerland. This article is an open access article distributed under the terms and conditions of the Creative Commons Attribution (CC BY) license (https:// creativecommons.org/licenses/by/ $4.0 /)$

\begin{abstract}
The food waste reduction through an efficient recovery of its valuable building molecules has become an important topic with a positive effect on the economy and the environment. In this work, the revalorization of slaughterhouse calf fleshing meat through its enzymatic hydrolysis is proposed. The proteolytic activity of 11 enzymes was initially screened and the four most efficient enzymes (papain, trypsin, pancreatin, and bromelain) were selected. The molecular profiling of the different protein/peptide fractions by the Linear Trap Quadrupole-OrbiTrap technique showed compositional differences due to the specificity of the enzymes' cleavage sites. In order to find a potential reuse of these hydrolysates, the analysis of antioxidant and, for the first time on fleshing meat hydrolysates, of anti-tyrosinase activities, was performed. Papain-digested samples were those showing the highest inhibition activity of tyrosinase enzyme (55.6\%) as well as the highest antioxidant activity (3.52 $\mathrm{g}$ TEAC/L). In addition, the composition analysis of the lipid fraction was performed. The mono-unsaturated fatty acids resulted to be the most abundant lipid in all the samples with the exception of pancreatin-treated hydrolysates in which poly-unsaturated fatty acids were predominant. The present results seemed to support a possible valorization of isolated fractions from calf fleshing by-products, as food or feed ingredients, by the implementation of fraction isolation within the meat-processing pipeline.
\end{abstract}

Keywords: by-products valorization; protease; bioactive peptides; protein hydrolysates; fatty acids

\section{Introduction}

The recovery of food waste and by-products has become a hot topic, because of the rising global demand of animal protein-based food products up to $70 \%$ by 2050 [1]. This fact is due to the population growth and to the adoption, in underdeveloped countries, of Westernized eating habits. Furthermore, this expected increase of animal protein product consumption leads to a simultaneous increase of the production of food-related waste [2] Interestingly, depending on animal species, after the slaughtering, only $30-40 \%$ of meatprocessing products is used for human consumption [3]. Particularly in the case of beef, that $44 \%$ is considered as "meat" and the remaining $56 \%$, usually discarded, is composed of non-edible (e.g., specified risked materials, SRM) and edible parts (e.g., offal) [4]. The incorrect utilization or the non-utilization of these by-products causes loss of potential revenues and rising disposal costs for the producing companies [5]. An efficient and sustainable 
utilization of these by-products will have a positive economic and environmental impact. Moreover, these by-products could be exploited as a cheap source of valuable compounds, which could be recovered and recycled as functional additives or ingredients in different food or feed products [6].

Beef fleshing meat by-product is represented by the meat portion, which is directly attached to the bovine hides. This part is usually discarded and not recovered despite its potential as a valuable source of proteins. Different strategies have been proposed [7] for the recovery of fleshing meat. Previous studies reported the use of the enzymatic hydrolysis on fleshing meat from different animal species [8-11] with or without the chemical treatments of tanning process. More recently, the activity of six proteolytic enzymes was compared, and the protein fraction composition characterised [12]. The meat by-product hydrolysates could find valuable industrial applications in the food sector as they constitute a notable source of nutrients like amino acids, minerals, and vitamins, they can be used to improve technological functions (flavouring compounds, water binding agents, emulsifiers), enhance sensory qualities (colour, texture, flavour), and increase the shelf life [13]. Moreover, a prevalent fraction of the meat hydrolysates is constituted by bioactive peptides, which could be used for the production of functional ingredients. Bioactive peptides are defined as a short sequence of amino acids, which are not active within the structure of the parent protein but show a positive effect on the system of the body once released [14]. During the proteolysis, a high number of peptides are liberated, but only a few of them can exhibit determined health benefits and can be defined as bioactive peptides [15]. Some examples of bioactivities, which can affect the health of the consumers, are anti-hypertensive, antioxidant, anti-inflammatory, antimicrobial, anticancer, anti-thrombic, and opioid-like [14]. Oxidation in food is directly linked to its deterioration and, in particular, it affects lipids, carbohydrates, and proteins. In meat products, the most important effects of deterioration are colour changes, microbial growth, and lipid oxidation [16]. To prevent the oxidation in food, synthetic antioxidants are usually added to retard lipid oxidation [17] but their utilization is under strict regulation as they might be associated with health risk. On the other hand, enzymatic browning due to tyrosinase activity may further result in discolouration and reducing the nutritional value of foods [18] Therefore, nowadays, industries are searching for tyrosinase inhibitors to be used as browning preventing agents in nutraceutical and functional food sectors [19] or as anti-aging ingredients in cosmetic field [20]. This biological activity was usually ascribed to plant secondary metabolites $[18,21,22]$ and, recently, also to proteins and peptides coming from both animals and plants [23-25]. Anti-tyrosinase capacity of fleshing meat hydrolysates is reported here for the first time and could prove to have good possibilities of future exploitation already in the meat processing industries. In fact, the protein hydrolysates coming from meat by-products and showing anti-browning capacity could be valuable, both as preservatives for meat-based food products, as well as additives for active food packaging.

As regards fatty acid total content, saturated fatty acids are the preponderant in bovine meat. Because of the hydrogenation process of unsaturated fatty acids that make them saturated that occurs in bovine rumen due to its microflora, polyunsaturated fatty acid content is very low in bovine meat [26]. A study conducted on calf, young bull, and cow meat confirmed this fatty acid development [27]. Animal species, breed, age, and farmed technique can affect fatty acids composition [28].

In view of the reduction of large amounts of by-products and wastes generated during meat processing, the aim of this study was to test the activity of eleven proteases in different reaction conditions for the hydrolysis of bovine fleshing meat and, after the selection of the four most efficient enzymes, to determine the molecular profile of the protein and lipid fractions of obtained hydrolysates. The peptide hydrolysates were also tested in vitro to assess their antioxidant and, for the first time, their anti-tyrosinase activities in view of their possible exploitation in the food and feed industrial sectors. 


\section{Materials and Methods}

\subsection{Reagents and Solvents}

Deionized water was obtained from a Millipore Alpha Q-Waters purification system (Billerica, MA, USA). Sodium dihydrogen phosphate, hydrochloric acid, acetonitrile, DL-cystine, dichloromethane, N-acetyl-L-cysteine, sodium tetraborate decahydrate, DLisoleucine and DL-norleucine, $30 \%$ hydrogen peroxide solution, sulfuric acid, formic acid, trifluoroacetic acid, 2'-azino-bis-3-ethylbenzothiazoline-6-sulfonic acid (ABTS), potassium persulfate, Trolox, tyrosinase from mushroom, and L-DOPA were purchased from SigmaAldrich (St. Louis, MO, USA). Copper oxide was obtained from Carlo Erba (Milan, Italy). O-phthalaldehyde and boric acid were bought from Fluka (Buchs, Switzerland). Sodium dodecyl sulfate was purchased from Biorad (Hercules, CA, USA). Kjeldahl tablets defoamers and catalyst $3.5 \mathrm{~g} /$ tablet were purchased from Merck (Darmstadt, Germany). AccQ-Fluor reagent kit was obtained from Waters (Milford, MA, USA).

\subsection{Raw Material}

Samples of calf fleshing were provided by Inalca Industria Alimentare Carni SpA (Castelvetro di Modena, Italy). The samples (three biological replicates of about $600 \mathrm{gFW}$ each collected on a single slaughter day) were obtained from commercial breeds slaughtered in an abattoir at Inalca and transported to the University laboratories on the day of the slaughtering. The samples were grounded and homogenized in a kitchen blender (Kenwood FP735 $1000 \mathrm{~W}$, Tokyo, Japan) at $3{ }^{\circ} \mathrm{C}$. The samples were divided in $5.0 \pm 0.3 \mathrm{gFW}$ (grams of fresh weight) aliquots and immediately frozen at $-80^{\circ} \mathrm{C}$ until further analyses.

\subsection{Raw Material Chemical Composition}

Moisture content of fleshing was determined using the official AOAC (Association of Official Analytical Chemists) method [29] according to Anzani et al. [12].

\subsection{Proteases Digestion}

Just before hydrolysis, $10 \mathrm{~mL}$ of $10 \mathrm{mM}$ sodium-phosphate buffer $(\mathrm{pH} 7.5)$ were added to $5 \mathrm{gFW}$ of fleshing; the final $\mathrm{pH}$ of the digestion mixture was $7.2 \pm 0.2$. Initially, the proteolytic activity of 11 different commercial proteases were initially tested following these conditions: $2 \% \mathrm{E} / \mathrm{S}$ ratio (g enzyme/gFW sample), $4 \mathrm{~h}$ of incubation time, $\mathrm{pH}$ 7.2-7.4 (with the exception of pepsin, which was tested at $\mathrm{pH}$ 3.0, in water acidified by chloridric acid), $140 \mathrm{rpm}$ stirring, and specific temperature enzyme according to manufacturer's instructions: Alcalase $1.5 \mathrm{MG}\left(60^{\circ} \mathrm{C}\right.$, Novozymes A/S, Denmark), protamex $\left(60^{\circ} \mathrm{C}\right.$, Novozymes A/S, Denmark), papain from Carica papaya $\left(60^{\circ} \mathrm{C}\right.$, Sigma-Aldrich, Milan, Italy), neutrase $1.5 \mathrm{MG}\left(50^{\circ} \mathrm{C}\right.$, Novozymes A/S, Denmark), flavourzyme $500 \mathrm{MG}\left(50^{\circ} \mathrm{C}\right.$, Novozymes A/S, Denmark), pancreatin from porcine pancreas $\left(37^{\circ} \mathrm{C}\right.$, Sigma-Aldrich, Milan, Italy), trypsin (type A, 13,000-20,000 U/mg, $37^{\circ} \mathrm{C}$, Sigma-Aldrich, Milan, Italy), trypsin from porcine pancreas (type B, 1000-2000 U/mg, $37^{\circ} \mathrm{C}$, Sigma-Aldrich, Milan, Italy), bromelain from pineapple stem $\left(37^{\circ} \mathrm{C}\right.$, Sigma-Aldrich, Milan, Italy), $\alpha$-chymotrypsin from bovine pancreas $\left(37^{\circ} \mathrm{C}\right.$, Sigma-Aldrich, Milan, Italy), and pepsin from porcine gastric mucosa $\left(37^{\circ} \mathrm{C}, \mathrm{pH}\right.$ 3.0, Sigma-Aldrich, Milan, Italy). Control samples without any enzyme addition (ND, not digested) were performed by incubating the samples for $4 \mathrm{~h}, 140 \mathrm{rpm}$ stirring, at each incubation temperature (ND $60{ }^{\circ} \mathrm{C}, 50^{\circ} \mathrm{C}$ and $\left.37^{\circ} \mathrm{C}\right)$. The enzyme was inactivated by boiling the samples in a water bath for $5 \mathrm{~min}$. The samples were cooled on ice and centrifuged at $5000 \mathrm{rpm}$ for $15 \mathrm{~min}$ at $4{ }^{\circ} \mathrm{C}$ (Eppendorf centrifuge $5804 \mathrm{R}$, rotor A 4-44, Hamburg, Germany). After the centrifugation, three different fractions were observed: Pellet (residual solid material), intermediate liquid fraction (containing digested proteins/peptides/amino acids), upper fraction (containing lipids). The three fractions were separately collected and stored at $-20^{\circ} \mathrm{C}$ until following analyses.

Because of the gelatine formation in ND $\left(60^{\circ} \mathrm{C}, 4 \mathrm{~h}\right), \alpha$-chymotrypsin $\left(60^{\circ} \mathrm{C}, 4 \mathrm{~h}\right)$, and pepsin $\left(37^{\circ} \mathrm{C}, 4 \mathrm{~h}\right)$ samples, it was not possible to separate the three sub-fractions in these treatments, therefore they were discarded. 
To optimize the E/S ratio and the time of incubation, several digestion treatments were performed for each type of enzyme. The four best digestion conditions were selected, yielding the highest amount of hydrolyzed proteins in the intermediate fraction measured as $g$ of bovine serum albumin equivalents per liter (g BSA eq/L) [30]. The complete list of tested hydrolysis conditions and related yields is summarized in Supplementary Table S1.

\subsection{Quantification of Free and Total Amino Acids, SDS-PAGE and Degree of Hydrolysis (DH) Analyses}

The free amino acid determination in intermediate protein-based fractions, performed by high-performance liquid chromatography with fluorescence detection (HPLC/FLD) after AccQ•Tag derivatization, the SDS-PAGE (Sodium Dodecyl Sulphate - PolyAcrylamide Gel Electrophoresis) analysis, and the DH analysis by (o-phthaldialdehyde) OPA method, were performed as reported by Anzani et al. [12]. The DH was calculated as follows:

$$
\mathrm{DH}(\%)=\left(\mathrm{N}_{\text {free }} / \mathrm{N}_{\text {total }}\right) \times 100
$$

where $\mathrm{N}_{\text {free }}$ represent the moles of free nitrogen atoms from $\alpha$ - amino groups of amino acids after hydrolysis measured by the OPA assay, and $\mathrm{N}_{\text {total }}$ represent the total moles of nitrogen atoms in solution before hydrolysis calculated by the ratio of total grams of proteins and the average residual amino acid molecular mass (MW $110 \mathrm{Da}$ ).

\subsection{Peptide Identification by Linear Trap Quadrupole (LTQ)-Orbitrap Analyses}

Peptide identification was performed by LTQ-Orbitrap analyses according to a method previously reported [12].

\subsection{Fatty Acid Analysis}

The fatty acid composition of upper fractions was determined as fatty acid methyl esters (FAMEs) by capillary gas chromatography analysis after alkaline treatment [31]. Methyl tridecanoate (C13:0, $2 \mathrm{mg} / \mathrm{mL}$ ) was used as internal standard, and a GC 2010 Plus gas chromatograph (Shimadzu Corporation, Kyoto, Japan) equipped with a flame ionization detector (FID) and an AOC-20s auto sampler (Shimadzu Corporation) was used, according to Verardo et al. [32] with slight modifications. A BPX70 fused silica capillary column $(10 \mathrm{~m} \times 0.1 \mathrm{~mm}$ i.d. $0.2 \mu \mathrm{m}$ film thickness; SGE Analytical Science, Ringwood, VIC. Australia) was used. The injector and flame ionization detector temperatures were set at $250{ }^{\circ} \mathrm{C}$. Hydrogen was used as carrier gas at a flow rate of $0.8 \mathrm{~mL} / \mathrm{min}$. The oven temperature was held at $50^{\circ} \mathrm{C}$ for $0.2 \mathrm{~min}$, increased to $175^{\circ} \mathrm{C}$ at $120^{\circ} \mathrm{C} / \mathrm{min}$, held at $175^{\circ} \mathrm{C}$ for $2 \mathrm{~min}$, and finally increased from 175 to $220^{\circ} \mathrm{C}$ at $20^{\circ} \mathrm{C} / \mathrm{min}$. Samples were injected in split mode $(0.3 \mu \mathrm{L})$ with a split ratio set at 1:100. Peak identification was accomplished by comparing peak retention time with GLC-463 standard mixture from Nu-Check (Elysian, MN, USA) and FAME 189-19 standard mixtures from Sigma-Aldrich Chemicals (St. Louis, MO, USA) and expressed as weight percentage of total FAMEs. FAMEs composition was measured in 2 replicates for each lipid extract $(n=6)$ and each analysis lasted $7 \mathrm{~min}$.

\subsection{Antioxidant and Anti-Tyrosinase Activity Evaluation}

In all experiments, in vitro antioxidant activity of intermediate fractions was assessed by the 2'-azino-bis-3-ethylbenzothiazoline-6-sulfonic acid (ABTS) assay as reported by Ferri et al. [33]. The results were expressed as Trolox Equivalents Antioxidant Capacity (TEAC) by means of a dose-response calibration curve (between 0 and $2.5 \mu \mathrm{g}$ of Trolox). Anti-tyrosinase capacity was measured by an optimized enzyme inhibition assay [24] The brown color formation kinetic was detected (absorbance at $490 \mathrm{~nm}$ ) in the presence of $10 \mathrm{U}$ of tyrosinase, $2 \mathrm{mM} \mathrm{L-DOPA}$ (3,4-dihydroxy-L-phenylalanine), and the sample. The results were expressed as $\%$ of inhibition. 


\subsection{Statistical Analysis}

All the treatments were performed in two biological replicates and two technical replicates were analyzed for each repetition. Statistically significant differences were analyzed among the same type of analytical data, related to different hydrolysate samples, by using one-way ANOVA followed by post hoc Tukey's multiple pairwise comparison $(p<0.05)$ (R Software, version 1.3.5, R Core Tram, Vienna, Austria).

\section{Results and Discussion}

\subsection{Calf Fleshing Bulk Characterization}

Non-treated calf fleshing meat samples (ND) were analyzed. Proteins, fat, and moisture percentages found were $16 \%( \pm 4), 14 \%( \pm 2)$, and $72 \%( \pm 3)$, respectively, over the total wet weight. Previous data obtained on the same initial by-product [12] showed the presence of a lower fat content. This difference could be ascribable to calf samples' biological variability, which could show a slightly different composition of the residual fleshing. Conversely, the distribution of total amino acids (Table 1) was similar to that reported by Anzani et al. [12], with Hyp, Glu, and Pro being the most abundant. In agreement with Rai et al. [34] and Bhaskar et al. [35], the presence of these amino acids suggested that fleshing is constituted by a great amount of collagen because of its proximity to the skin. A further important point of discussion is to evaluate the impact of the fleshing from a nutritional point of view. Therefore, the amount of essential amino acids was compared with that of a reference standard amino acid profile from raw lean beef [36]. Fleshing showed a lower amount of essential amino acids compared to the reference, demonstrating the lower nutritional value of fleshing compared to lean meat, given the presence of the collagen as fleshing main component. Collagen, as previously mentioned, is rich in Hyp, Pro, and Glu, and consequently caused a decrease of the essential amino acids in fleshing.

Table 1. High-performance liquid chromatography with fluorescence detection (HPLC-FLD) analysis of amino acid distribution in initial calf fleshing by-products given as percentage of the total amino acid pool.

\begin{tabular}{ccc}
\hline Amino Acids & \% on Total Amino Acids & Reference (\%) \\
\hline Hyp & $12.1 \pm 0.6$ & 1.4 \\
Asp & $7.0 \pm 0.5$ & 9.4 \\
Ser & $3.2 \pm 0.1$ & 4.2 \\
Glu & $13.2 \pm 0.7$ & 15.6 \\
Gly & $8.2 \pm 0.6$ & 7.1 \\
His & $2.2 \pm 0.3$ & 3.4 \\
Arg & $6.3 \pm 0.5$ & 6.8 \\
Thr & $3.4 \pm 0.3$ & $\mathbf{4 . 0}$ \\
Ala & $5.3 \pm 0.8$ & 6.5 \\
Pro & $10.7 \pm 1.2$ & 5.3 \\
Tyr & $2.7 \pm 0.4$ & 3.2 \\
Val & $3.3 \pm \mathbf{0 . 2}$ & $\mathbf{5 . 1}$ \\
Met & $\mathbf{3 . 4} \pm \mathbf{0 . 3}$ & $\mathbf{2 . 7}$ \\
Lys & $\mathbf{6 . 6} \pm \mathbf{0 . 4}$ & $\mathbf{8 . 6}$ \\
Ile & $\mathbf{3 . 3} \pm \mathbf{0 . 3}$ & $\mathbf{4 . 6}$ \\
Leu & $5.8 \pm \mathbf{0 . 5}$ & $\mathbf{8 . 1}$ \\
Phe & $\mathbf{3 . 4} \pm \mathbf{0 . 3}$ & $\mathbf{4 . 1}$ \\
\hline
\end{tabular}

Data in bold show the amounts of essential amino acids. The reference is represented by standard amino acid profile from raw lean beef [36]. Data (means \pm SD) are expressed in (\%).

\subsection{Optimization of the Enzymatic Reaction}

In preliminary digestion trials, 11 different proteases were tested on calf fleshing samples. To assess the efficiency of the digestion reactions, the hydrolyzed protein amount as well as the antioxidant activity were measured, by spectrophotometrical assays, in the intermediate liquid protein-based fraction of hydrolysates (Supplementary Table S1). After preliminary trials, the four best digestion conditions, yielding the highest amount of 
digested proteins, were selected and were, respectively: papain: $10 \% \mathrm{E} / \mathrm{S}, 2 \mathrm{~h} 60^{\circ} \mathrm{C}$; pancreatin $10 \% \mathrm{E} / \mathrm{S}, 2 \mathrm{~h} 37^{\circ} \mathrm{C}$; bromelain $10 \% \mathrm{E} / \mathrm{S}, 2 \mathrm{~h} 37^{\circ} \mathrm{C}$; trypsin (type B): $10 \% \mathrm{E} / \mathrm{S}, 4 \mathrm{~h} 37^{\circ} \mathrm{C}$. Overall, the highest amount of hydrolyzed proteins was equally measured in samples obtained with $10 \%$ papain and $10 \%$ trypsin B (77.31 and $77.65 \mathrm{~g} \mathrm{BSA}$ eq/L, respectively) followed by bromelain (68.88 g BSA eq/L) and pancreatin (58.76 g BSA eq/L) (Figure 1a, Supplementary Table S1).
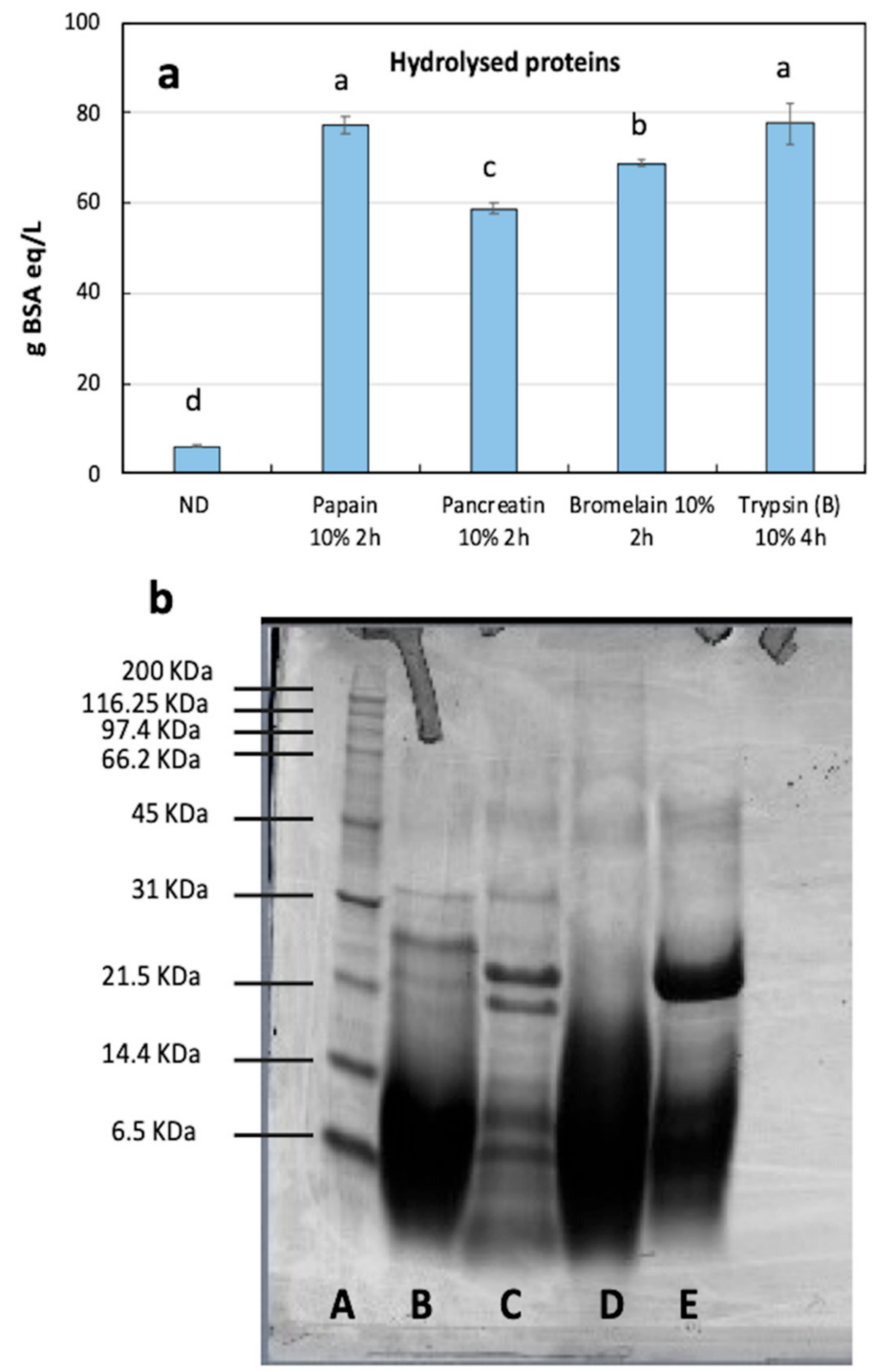

Figure 1. Optimized hydrolysis. (a) Quantification of hydrolyzed proteins (g BSA eq/L) in intermediate fractions obtained after calf fleshing hydrolysis at different digestion conditions. ND, average of not-digested control at $50{ }^{\circ} \mathrm{C}$ and $37^{\circ} \mathrm{C}$. Statistically significant differences among different hydrolysate samples were indicated by different letters, according to one-way ANOVA followed by post hoc Tukey's multiple pairwise comparison $(p<0.05)$. Data are the mean \pm SD $(n=4)$. (b) SDS-PAGE (Sodium Dodecyl Sulphate - PolyAcrylamide Gel Electrophoresis) profile of samples: A, standard marker; B, papain hydrolysate; C, pancreatin hydrolysate; D, bromelain hydrolysate; E, trypsin (B) hydrolysate.

The SDS-PAGE sample profile (Figure 1b) showed that the hydrolysates were constituted by peptides with a molecular weight below $31 \mathrm{kDa}$. However, there were some differences among the samples as consequence of the different cleavage sites of each enzyme, which could attack the sequence within specific amino acid residues or be unspecific. Of the selected enzymes, bromelain does not have a specific cleavage site while papain is a 
cysteine endopeptidase, hydrolyzing proteins, peptides, amides, and esters of amino acids and peptides, with the specific target of Arg, Lys, Glu, His, Gly, and Tyr bonds [37]. However, if the incubation is prolonged, further bonds are split. According to Olsen et al. [38], the cleavage site of trypsin is very specific cutting exclusively the C-terminal Arg or Lys. On the contrary, pancreatin cleavage site is not specific being a mixture of different type of enzymes such as protease, amylase, and lipase. However, the profile of the sample treated with pancreatin and trypsin type B resulted almost similar, with a blurred band lower than $14.4 \mathrm{kDa}$ and 2 bands around $21.5 \mathrm{kDa}$ (probably because of the high concentration in the sample treated with trypsin showed only one blurred band) (Figure 1b, lanes C and E).

\subsection{Protein Fraction Analysis}

The degree of hydrolysis (DH), which is directly linked to the enzyme proteolytic activity, was determined on selected samples on the basis of the number of the cleaved peptide bonds and on the amount of free amino acids present in solution [39]. DH was determined by monitoring the reaction of the free amino groups with OPA depending on the protein material released in solution. The sample treated with papain showed the highest $\mathrm{DH}(70 \% \pm 2)$, followed by bromelain and pancreatin $(55 \% \pm 1$ and $60 \% \pm 5$, respectively), which resulted to be not significantly different $(p<0.05)$. The sample obtained with trypsin B showed the lowest $\mathrm{DH}(25 \% \pm 0.4)$ possibly due to the highest specificity of this enzyme, which is able to cleave the sequence after Arg and Lys and therefore release long peptides and less free amino acids. The present $\mathrm{DH}$ results were higher than literature data; for example, Zhang et al. [9] treated bovine collagen with six different proteases and diverse pre-treatments, obtaining DH always lower than $20 \%$. The content and distribution of free amino acids were also measured and are reported in Table 2.

Table 2. Free amino acid distribution of the hydrolysates obtained by enzymatic hydrolysis of calf fleshing meat.

\begin{tabular}{ccccc}
\hline Amino Acids & Papain & Pancreatin & Bromelain & Trypsin (B) \\
\hline Hyp & $3.46 \pm 0.33^{\mathrm{b}}$ & $3.54 \pm 0.07^{\mathrm{b}}$ & $2.79 \pm 0.60^{\mathrm{b}}$ & $5.75 \pm 0.30^{\mathrm{a}}$ \\
Asp & $0.14 \pm 0.03^{\mathrm{c}}$ & $1.81 \pm 0.01^{\mathrm{a}}$ & $0.81 \pm 0.01^{\mathrm{b}}$ & $1.78 \pm 0.36^{\mathrm{a}}$ \\
Ser & $3.55 \pm 0.06^{\mathrm{a}}$ & $4.17 \pm 0.66^{\mathrm{a}}$ & $3.73 \pm 0.20^{\mathrm{a}}$ & $1.75 \pm 0.01^{\mathrm{b}}$ \\
Glu & $4.66 \pm 0.04^{\mathrm{b}}$ & $6.86 \pm 0.25^{\mathrm{a}}$ & $2.44 \pm 0.37^{\mathrm{c}}$ & $2.77 \pm 0.05^{\mathrm{c}}$ \\
Gly & $9.00 \pm 0.02^{\mathrm{a}}$ & $1.67 \pm 0.15^{\mathrm{c}}$ & $3.27 \pm 0.13^{\mathrm{b}}$ & $1.57 \pm 0.04^{\mathrm{c}}$ \\
His & $2.62 \pm 0.06^{\mathrm{c}}$ & $5.80 \pm 0.08^{\mathrm{a}}$ & $4.65 \pm 0.16^{\mathrm{b}}$ & $2.47 \pm 0.02^{\mathrm{c}}$ \\
Arg & $14.58 \pm 0.29^{\mathrm{a}}$ & $16.63 \pm 1.69^{\mathrm{a}}$ & $3.74 \pm 0.34^{\mathrm{b}}$ & $14.27 \pm 1.04^{\mathrm{a}}$ \\
Thr & $2.93 \pm 0.08^{\mathrm{b}}$ & $3.79 \pm 0.07^{\mathrm{b}}$ & $8.37 \pm 0.24^{\mathrm{a}}$ & $3.48 \pm 0.05^{\mathrm{b}}$ \\
Ala & $3.44 \pm 0.03^{\mathrm{b}}$ & $3.70 \pm 0.67^{\mathrm{a}}$ & $2.29 \pm 0.09^{\mathrm{b}}$ & $3.28 \pm 0.80^{\mathrm{b}}$ \\
Pro & $7.67 \pm 0.04^{\mathrm{b}}$ & $1.32 \pm 0.23^{\mathrm{c}}$ & $11.89 \pm 0.62^{\mathrm{a}}$ & $1.36 \pm 0.21^{\mathrm{c}}$ \\
Tyr & $7.89 \pm 0.21^{\mathrm{a}}$ & $8.93 \pm 0.86^{\mathrm{a}}$ & $4.96 \pm 0.47^{\mathrm{b}}$ & $7.52 \pm 0.73^{\mathrm{a}}$ \\
Val & $1.85 \pm 0.09^{\mathrm{c}}$ & $4.43 \pm 0.15^{\mathrm{a}}$ & $3.08 \pm 0.01^{\mathrm{b}}$ & $3.46 \pm 0.69^{\mathrm{b}}$ \\
Met & $3.93 \pm 0.13^{\mathrm{b}}$ & $4.20 \pm 0.41^{\mathrm{b}}$ & $4.55 \pm 0.22^{\mathrm{b}}$ & $5.69 \pm 0.03^{\mathrm{a}}$ \\
Lys & $15.36 \pm 0.13^{\mathrm{b}}$ & $14.89 \pm 1.84^{\mathrm{b}}$ & $10.55 \pm 0.06^{\mathrm{c}}$ & $22.51 \pm 1.89^{\mathrm{a}}$ \\
Ile & $3.96 \pm 0.12^{\mathrm{b}}$ & $4.05 \pm 0.20^{\mathrm{b}}$ & $19.26 \pm 0.23^{\mathrm{a}}$ & $4.47 \pm 0.69^{\mathrm{b}}$ \\
Leu & $11.20 \pm 0.47^{\mathrm{a}}$ & $7.82 \pm 0.33^{\mathrm{c}}$ & $9.04 \pm 0.16^{\mathrm{b}}$ & $9.45 \pm 0.38^{\mathrm{b}}$ \\
Phe & $3.75 \pm 0.33^{\mathrm{c}}$ & $6.40 \pm 0.58^{\mathrm{b}}$ & $4.59 \pm 0.09^{\mathrm{c}}$ & $8.40 \pm 0.45^{\mathrm{a}}$ \\
\hline
\end{tabular}

Data (means \pm SD) are expressed in (\%). Different lowercase letters on the same row show significantly different values for samples digested with different enzyme determined one-way ANOVA followed by post hoc Tukey's multiple pairwise comparison $(p<0.05)$.

Particularly in the case of trypsin B and pancreatin digested samples, the most abundant amino acids were Arg (14.27 and 16.63\%, respectively) and Lys (22.51 and $14.89 \%$, respectively), according to the specificity of the cleavage site. The sample treated with papain was rich of $\operatorname{Arg}(14.58 \%)$, Lys $(15.36 \%)$, Leu $(11.20 \%)$, and Gly $(9.00 \%)$, while that obtained with bromelain showed high levels of Ile (19.26\%), Pro (11.89\%), Lys (10.55\%), Leu $(9.04 \%)$, and Thr $(8.37 \%)$. 
Moreover, the hydrolysates were also analyzed by high-resolution mass spectrometry to identify the most abundant peptides present in the origin proteins (Table 3). In the pancreatin and papain hydrolysates most of the detected peptides derived from collagen. On the other side, in trypsin B-derived digestates the most abundant peptides were originated from muscular protein, such as myosin.

Table 3. Identification by Linear Trap Quadrupole-OrbiTrap of the main peptides in digestates obtained after enzymatic hydrolysis of calf fleshing meat, and of the proteins of origin. Proteins are listed according to the highest number of peptides generated [12]. AA, amino acids.

\begin{tabular}{cccc}
\hline Enzyme & $\begin{array}{c}\text { Identified } \\
\text { Peptides }\end{array}$ & Parent Protein & $\begin{array}{c}\text { Average Peptide } \\
\text { Length (N } \mathbf{N A A}^{\circ}\end{array}$ \\
\hline Papain & 78 & Collagen alpha-1(I) chain & 14 \\
& 71 & Actin, alpha skeletal muscle & 11 \\
& 56 & Collagen alpha-2(I) chain & 13 \\
& 54 & Collagen alpha-1(II) chain & 12 \\
Pancreatin & 30 & Myosin-1 & 11 \\
& 70 & Titin & 12 \\
& 57 & Collagen alpha-1(I) chain & 11 \\
& 53 & Collagen alpha-2(I) chain & 10 \\
& 29 & Collagen, type III, alpha 1 & 14 \\
Bromelain & 24 & IgG heavy chain & 18 \\
& 24 & Collagen alpha-1(I) & 9 \\
& 17 & Hemoglobin subunit beta & 23 \\
& 15 & Hemoglobin subunit alpha & 25 \\
& 15 & Collagen alpha-2(I) chain & 9 \\
& 13 & Myosin light chain 1/3, & 13 \\
& skeletal muscle isoform & 11 \\
\hline Trypsin (B) & 59 & Titin & 11 \\
& 46 & Myosin-2 & 10 \\
& 28 & Myosin-1 & 13 \\
& 23 & Collagen alpha-1(I) chain & 12 \\
\hline 10 & Myosin-7 &
\end{tabular}

\subsection{Antioxidant and Anti-Tyrosinase Activity}

The antioxidant activity was assayed in intermediate fraction of all the samples (Supplementary Table S1) and the highest values were obtained using $10 \%$ papain (on average $3.22 \mathrm{~g}$ TEAC/L) (Supplementary Table S1, Figure 2a). These results are comparable with literature data by Ryder et al. [40] who obtained hydrolysates, from bovine connective tissue treated with different fungal proteases, showing an average Trolox equivalence lower than $10 \mathrm{mmol} / \mathrm{L}$ (equals to $2.5 \mathrm{~g}$ TEAC/L), increased to $45 \mathrm{mmol} / \mathrm{L}$ (equals to $11 \mathrm{~g}$ TEAC/L) by a more complex proteolytic protease preparation.

In addition, the papain-sample ( $10 \%$ for $2 \mathrm{~h}$ ) also showed the highest inhibition activity (55.6\%) of tyrosinase enzyme, while the sample digested with bromelain (10\% for $2 \mathrm{~h}$ ) showed the lowest (23.6\%) (Figure $2 b$ ). To the best of the authors' knowledge, this is the first report on anti-tyrosinase activities of fleshing meat hydrolysates. A comparison can be done with tyrosinase inhibitory activity of a fish meat (Scomber japonicus) hydrolysed by subcritical water treatment, which shows best activities between $48 \%$ and $65.5 \%$ of inhibition depending on process conditions [41]. These results were, therefore, very promising, as nowadays, the interest in anti-tyrosinase ingredients is increasing among several industries $[19,20]$. Fleshing meat hydrolysates exerting this type of bioactivity can be exploited as browning-preventing agents already in the meat-processing chain, for example as preservative ingredients in food preparations, or as additives for the production of food active packaging. 

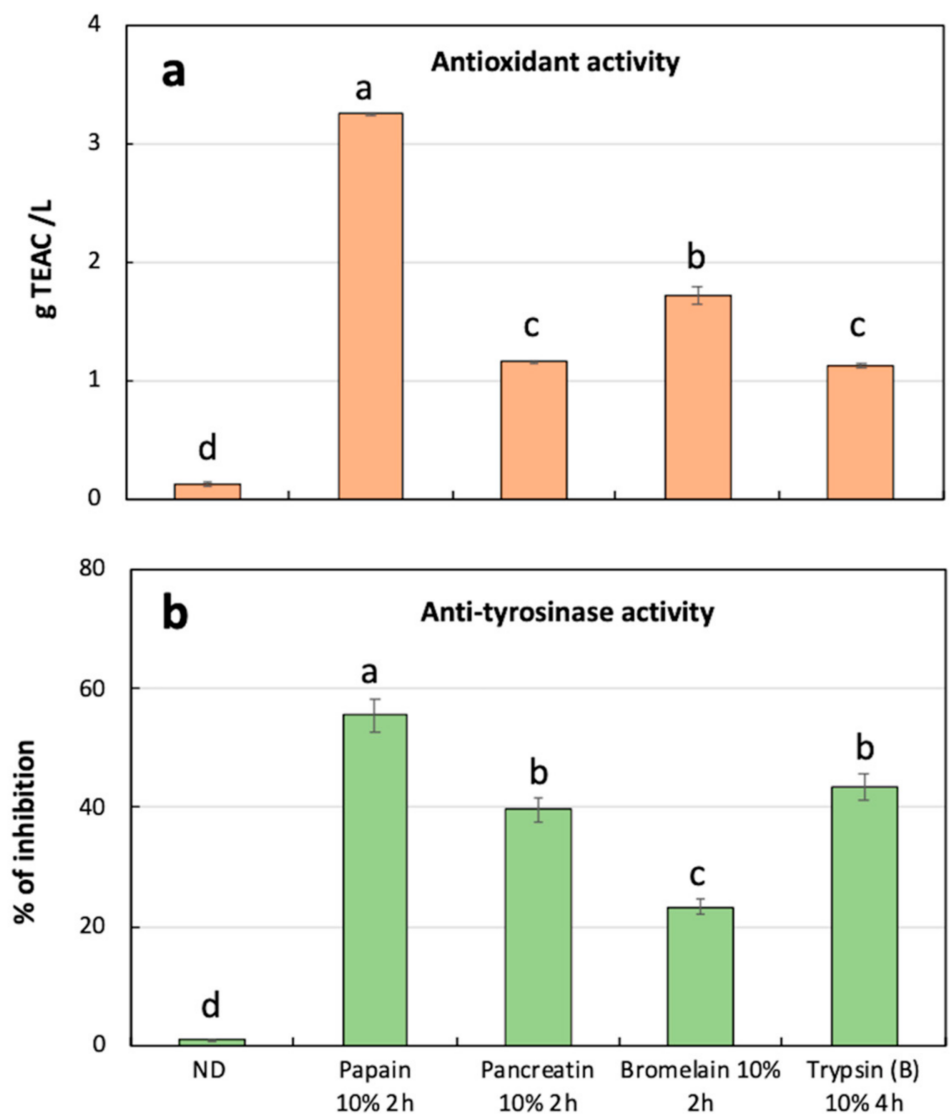

Figure 2. Quantification of antioxidant activity (a) and anti-tyrosinase activity (b) in intermediate fractions obtained after calf fleshing hydrolyses at different digestion conditions. ND, average of not digested control at $50^{\circ} \mathrm{C}$ and $37^{\circ} \mathrm{C}$. Statistically significant differences among the same analysis were indicated by different letters, according to one-way ANOVA followed by post hoc Tukey's multiple pairwise comparison $(p<0.05)$. TEAC, Trolox equivalents antioxidant capacity. Data are the mean $\pm \mathrm{SD}(n=4)$.

\subsection{Fatty Acid Composition}

A total of 17 individual fatty acids were identified and quantified in the upper fraction of differently hydrolyzed samples. As shown in Table 4, oleic acid (C18:1 cis9) was the most abundant fatty acid in all digestates, ranging from about 39.59 to $42.80 \%$. The second major fatty acid detected was palmitic acid (C16:0, 24-26\%), followed by stearic acid (C18:0, 7-9\%), palmitoleic acid (C16:1 cis, 5-6\%), myristic acid (C14:0, 5-6\%), and linoleic acid (C18:2 n6, 4-5\%). The samples digested with four different enzymes differed for the fatty acid composition but not for the concentration of them, that did not show significant differences $(p<0.05)$.

As shown in Table 4, the sample digested with papain showed the most complete fatty acids composition, which was the same of sample digested with trypsin, except for $\mathrm{C} 18: 1 \mathrm{t} 9$ that was absent. Samples treated with pancreatin and bromelain showed a more limited fatty acids composition. In particular, C12:0, C15:0, C16:1t, C17:0, C17:1, C18:1t9, $\mathrm{C} 18: 3 \mathrm{n} 3$, and C20:0 were absent in these two samples; C20:3n6 was present only in the sample digested with pancreatin. Saturated fatty acids (SFA) were present in considerable amounts, from 39.52 to $40.46 \%$, whereas mono-unsaturated fatty acids (MUFA) were the class more abundant in all the samples ranging from 50.20 to $54.60 \%$ without significant differences $(p<0.05)$ for both classes among the different samples. Polyunsaturated fatty acids (PUFA), instead, showed a significantly higher amount in the sample digested with pancreatin (10.03\%) and in a range from 4.99 to $6.39 \%$ in the other three samples. The low PUFA content of the analyzed calf's by-products is related to animal nature, and rumen microflora in bovine rumen is responsible for the hydrogenation pro- 
cess, which takes place at unsaturated fatty acids, increasing the total SFA amount [26,27]. Compared to the literature [42-44], the results obtained in this work revealed lower amount of saturated and polyunsaturated fatty acids and higher concentration of monounsaturated fatty acids. In fact, in studies conducted by Baggio et al. [42], Muchenje et al. [43], and Brugiapaglia et al. [44], SFA concentrations were, respectively, 47-48\%, 44-45\% and 46-49\%; MUFA concentrations were 39-40\%, 34-36\%, and 32-42\%; and PUFA concentrations were $12-14 \%, 19-22 \%$, and $41-22 \%$.

Table 4. Fatty acids (FA) identification and quantification of the hydrolysates obtained by enzymatic hydrolysis of fleshing meat.

\begin{tabular}{ccccc}
\hline FA & Papain & Pancreatin & Bromelain & Trypsin (B) \\
\hline C12:0 & $0.69 \pm 0.00$ & n.d. & n.d & $0.51 \pm 0.02$ \\
C14:0 & $5.82 \pm 0.09$ & $5.88 \pm 0.04$ & $5.66 \pm 0.30$ & $5.41 \pm 0.33$ \\
C14:1c & $2.30 \pm 0.19$ & $2.67 \pm 0.56$ & $3.79 \pm 0.15$ & $2.14 \pm 0.01$ \\
C15:0 & $0.31 \pm 0.01$ & n.d & n.d & $0.28 \pm 0.00$ \\
C16:0 & $24.66 \pm 0.03$ & $23.99 \pm 1.95$ & $26.55 \pm 0.38$ & $24.72 \pm 0.19$ \\
C16:1 t & $0.37 \pm 0.02$ & n.d & n.d & $0.27 \pm 0.07$ \\
C16:1 c & $5.80 \pm 0.02$ & $5.89 \pm 0.60$ & $5.88 \pm 0.96$ & $5.92 \pm 0.28$ \\
C17:0 & $0.58 \pm 0.01$ & n.d & n.d & $0.59 \pm 0.07$ \\
C17:1 & $0,61 \pm 0.04$ & n.d & n.d & $0.64 \pm 0.10$ \\
C18:0 & $7.77 \pm 0.03$ & $9.91 \pm 0.66$ & $8.21 \pm 0.47$ & $7.59 \pm 0.40$ \\
C18:1 t9 & $1.56 \pm 0.11$ & n.d & n.d & n.d \\
C18:1 c9 & $40.52 \pm 0.02$ & $39.59 \pm 4.69$ & $42.80 \pm 1.97$ & $41.61 \pm 1.37$ \\
C18:1 c11 & $1.99 \pm 0.14$ & $2.06 \pm 0.42$ & $2.12 \pm 0.32$ & $2.13 \pm 0.10$ \\
C18:2 n6 & $4.91 \pm 0.15$ & $4.78 \pm 0.38$ & $4.99 \pm 0.95$ & $4.38 \pm 0.60$ \\
C18:3 n3 & $0.71 \pm 0.08$ & n.d & n.d & $0.90 \pm 0.08$ \\
C20:0 & $0.64 \pm 0.06^{\text {a }}$ & n.d & n.d & $0.42 \pm 0.01^{\mathrm{b}}$ \\
C20:3 n6 & $0.76 \pm 0.66$ & $5.24 \pm 0.77$ & n.d & $0.85 \pm 0.10$ \\
SFA & $40.46 \pm 0.08$ & $39.77 \pm 0.75$ & $40.41 \pm 1.16$ & $39.52 \pm 0.98$ \\
MUFA & $53.16 \pm 0.51$ & $50.20 \pm 3.15$ & $54.60 \pm 2.11$ & $54.36 \pm 1.40$ \\
PUFA & $6.39 \pm 0.59 \mathrm{~b}$ & $10.03 \pm 2.39^{\mathrm{a}}$ & $4.99 \pm 0.95^{\mathrm{c}}$ & $6.12 \pm 0.42^{\mathrm{b}}$
\end{tabular}

SFA, saturated fatty acid; MUFA, monounsaturated fatty acid; PUFA, polyunsaturated fatty acid. n.d., not determined. Data (means \pm SD) are expressed in $\mathrm{mg}$ FA/100 mg fatty acid methyl esters (FAME) (\%). Different letters on the same row show significantly different values for samples digested with different enzyme determined by one-way ANOVA followed by post hoc Tukey's multiple pairwise comparison $(p<0.05)$.

\section{Conclusions}

In the present paper, the best four enzyme protocols for the hydrolysis of calf fleshing meat were selected and optimized. These were: Papain $\left(10 \% \mathrm{E} / \mathrm{S}\right.$, for $2 \mathrm{~h}$ at $\left.60{ }^{\circ} \mathrm{C}\right)$; pancreatin $\left(10 \% \mathrm{E} / \mathrm{S}\right.$, for $2 \mathrm{~h}$ at $\left.37^{\circ} \mathrm{C}\right)$; bromelain $\left(10 \% \mathrm{E} / \mathrm{S}\right.$, for $2 \mathrm{~h}$ at $\left.37^{\circ} \mathrm{C}\right)$; and trypsin (type B) $\left(10 \% \mathrm{E} / \mathrm{S}\right.$, for $4 \mathrm{~h}$ at $\left.37^{\circ} \mathrm{C}\right)$. SDS-PAGE profile, free-amino acid contents, $\mathrm{DH}$, and peptide identification results pointed out that the differences between the hydrolysates were due to the specificity of the enzyme's cleavage site. In the case of the fatty acid composition, MUFA were the most abundant ranging from 50.20 to $54.60 \%$; whereas the digestate obtained with pancreatin showed the highest amount of PUFA $(10.03 \%)$. The obtained protein-based samples also showed both antioxidant and anti-tyrosinase biological activities with papain-digested samples displaying the highest bioactivities (up to $3.52 \mathrm{~g}$ TEAC/L antioxidant capacity and to $55.6 \%$ tyrosinase inhibition). These results demonstrated the potential use of the enzymatic hydrolysis as a way of recovering calf fleshing meat by the production of hydrolysates reach in proteins, peptides, and free amino acids with anti-oxidant and anti-tyrosinase activities, and of good quality fatty acids fractions like n-3 and n-6 series. As no solvents nor chemicals were used along the exploitation process, the present results suggest that a possible future valorization of isolated fractions from calf fleshing by-products, as food or feed ingredients, is feasible and could be implemented short term within the meat-processing pipeline. 
Supplementary Materials: The following are available online at https://www.mdpi.com/article/10 .3390 / foods10040755/s1, Table S1: Preliminary optimisation of calf fleshing meat digestion conditions and selection of most efficient proteases.

Author Contributions: Conceptualization, A.T. and T.T.; methodology, A.T., S.M. (Silvia Marzocchi) and T.T.; formal analysis, C.A., A.T., M.F., S.M. (Silvia Marzocchi), S.M. (Stefania Monari) and T.T.; investigation, C.A., M.F., S.M. (Silvia Marzocchi), S.M. (Stefania Monari) and T.T.; data curation, C.A., M.F., S.M. (Silvia Marzocchi), S.M. (Stefania Monari), A.T. and T.T.; writing-original draft preparation, A.T., S.M. (Silvia Marzocchi) and T.T.; writing—review and editing, A.T., M.F., S.M. (Silvia Marzocchi) and T.T.; supervision, A.T., M.F.C. and T.T.; funding acquisition, A.T., M.F.C. and T.T. All authors have read and agreed to the published version of the manuscript.

Funding: This research was funded by Italian Ministry of Education, University and Research, National Project Cluster Agrifood SO.FI.A. (SOstenibilità della Flliera Agroalimentare) (2013-2017, Grant Number CTN01_00230_450760).

Institutional Review Board Statement: Not applicable.

Informed Consent Statement: Not applicable.

Data Availability Statement: All data are available within the manuscript and Supplmentary Material.

Acknowledgments: Authors wish to thank Inalca Industria Alimentare Carni SpA (Castelvetro di Modena, Italy) that provided support in the form of meat sample research materials.

Conflicts of Interest: The authors declare no conflict of interest.

\section{References}

1. FAO. The Future of Food and Agriculture: Alternative Pathways to 2050. Available online: http://tools.foodsecurityportal.org/ fao-global-perspectives-studies2019 (accessed on 20 January 2021).

2. FAO. SAVE FOOD: Global Initiative on Food Loss and Waste Reduction. 2021. Available online: http://www.fao.org/save-food/ resources/en/ (accessed on 20 January 2021).

3. Ockerman, H.W.; Hansen, C.L. Introduction and history of processing animal by-products. In Animal By-Products Processing and Utilization; Ockerman, H.W., Hansen, C.L., Eds.; CRC Press: Boca Raton, FL, USA, 2000; pp. 1-22.

4. Russ, W.; Meyer-Pittroff, R. Utilizing waste products from the food production and processing industries. Crit. Rev. Food Sci. Nutr. 2004, 44, 57-62. [CrossRef] [PubMed]

5. Jayathilakan, K.; Sultana, K.; Radhakrishna, K.; Bawa, A.S. Utilization of by-products and waste materials from meat, poultry and fish processing industries: a review. J. Food Sci. Technol. 2012, 49, 278-293. [CrossRef] [PubMed]

6. Lynch, S.A.; Mullen, A.M.; O’Neill, E.; Drummond, L.; Alvarez, C. Opportunities and perspectives for utilisation of co-products in the meat industry. Meat Sci. 2018, 144, 62-73. [CrossRef] [PubMed]

7. Sundar, V.J.; Gnanamani, A.; Muralidharan, C.; Chandrababu, N.K.; Mandal, A.B. Recovery and utilization of proteinous wastes of leather making: A review. Rev. Environ. Sci. Biotechnol. 2011, 10, 151-163. [CrossRef]

8. Bajza, Z.; Vrucek, V. Thermal and enzymatic recovering of proteins from untanned leather waste. Waste Manag. 2001, 21, 79-84. [CrossRef]

9. Zhang, Y.H.; Olsen, K.; Grossi, A.; Otte, J. Effect of pretreatment on enzymatic hydrolysis of bovine collagen and formation of ACE-inhibitory peptides. Food Chem. 2013, 141, 2343-2354. [CrossRef] [PubMed]

10. Damrongsakkul, S.; Ratanathammapan, K.; Komolpis, K.; Tanthapanichakoon, W. Enzymatic hydrolysis of rawhide using papain and neutrase. J. Ind. Eng. Chem. 2008, 14, 202-206. [CrossRef]

11. Jian, S.; Wenyi, T.; Wuyong, C. Ultrasound-accelerated enzymatic hydrolysis of solid leather waste. J. Clean Prod. 2008, 16, 591-597. [CrossRef]

12. Anzani, C.; Prandi, B.; Tedeschi, T.; Baldinelli, C.; Sorlini, G.; Wierenga, P.A.; Dossena, A.; Sforza, S. Degradation of collagen increases nitrogen solubilisation during enzymatic hydrolysis of fleshing meat. Waste Biomass. Valor. 2018, 9, 1113-1119. [CrossRef]

13. Toldra, F.; Aristoy, M.C.; Mora, L.; Reig, M. Innovations in value-addition of edible meat by-products. Meat Sci. 2012, 92, 290-296. [CrossRef]

14. Korhonen, H.; Pihlanto, A. Bioactive peptides: Production and functionality. Int. Dairy J. 2006, 16, 945-960. [CrossRef]

15. Arihara, K.; Ohata, M. Functional meat products. In Handbook of Meat Processing; Toldrá, F., Ed.; Wiley-Blackwell: Ames, IA, USA, 2010; pp. 423-439.

16. Di Bernardini, R.; Harnedy, P.; Bolton, D.; Kerry, J.; O’Neill, E.; Mullen, A.M.; Hayes, M. Antioxidant and antimicrobial peptidic hydrolysates from muscle protein sources and by-products. Food Chem. 2011, 124, 1296-1307. [CrossRef]

17. Saiga, A.; Tanabe, S.; Nishimura, T. Antioxidant activity of peptides obtained from porcine myofibrillar proteins by protease treatment. J. Agric. Food Chem. 2003, 51, 3661-3667. [CrossRef] 
18. Wang, B.-S.; Chang, L.-W.; Wu, H.-C.; Huang, S.-L.; Chu, H.-L.; Huang, M.-H. Antioxidant and anti-tyrosinase activity of aqueous extracts of green asparagus. Food Chem. 2011, 127, 141-146. [CrossRef]

19. Yu, Z.; Zeng, W. Antioxidant, antibrowning, and cytoprotective activities of Ligustrum robustum (Rxob.) Blume extract. J. Food Sci. Technol. 2013, 78, C1354-1362.

20. Bose, B.; Choudhury, H.; Tandon, P.; Kumaria, S. Studies on secondary metabolite profiling, anti-inflammatory potential, in vitrophotoprotective and skin-aging related enzyme inhibitory activities of Malaxis acuminata, a threatened orchid of nutraceutical importance. J. Photochem. Photobiol. B 2017, 173, 686-695. [CrossRef]

21. Ferri, M.; Rondini, G.; Calabretta, M.M.; Michelini, E.; Vallini, V.; Fava, F.; Roda, A.; Minnucci, G.; Tassoni, A. White grape pomace extracts, obtained by a sequential enzymatic plus ethanol-based extraction, exert antioxidant, anti-tyrosinase and anti-inflammatory activities. New Biotechnol. 2017, 39, 51-58. [CrossRef] [PubMed]

22. Karioti, A.; Protopappa, A.; Megoulas, N.; Skaltsa, H. Identification of tyrosinase inhibitors from Marrubium velutinum and Marrubium cylleneum. Bioorgan. Med. Chem. 2007, 15, 2708-2714. [CrossRef] [PubMed]

23. Monari, S.; Ferri, M.; Russo, C.; Prandi, B.; Tedeschi, T.; Bellucci, P.; Zambrini, A.V.; Donati, E.; Tassoni, A. Enzymatic production of bioactive peptides from scotta, an exhausted by-product of ricotta cheese processing. PLoS ONE 2019, 14, e0226834. [CrossRef] [PubMed]

24. Ferri, M.; Graen-Heedfeld, J.; Bretz, K.; Guillon, F.; Michelini, E.; Calabretta, M.M.; Lamborghini, M.; Gruarin, N.; Roda, A.; Kraft, A.; et al. Peptide fractions obtained from rice by-products by means of an environment-friendly process show in vitro health-related bioactivities. PLoS ONE 2017, 12, e0170954. [CrossRef]

25. Schurink, M.; van Berkel, W.; Wichers, H.; Boeriu, C. Novel peptides with tyrosinase inhibitory activity. Peptides 2007, 28, 485-495. [CrossRef]

26. Mapiye, C.; Dugan, M.E.R.; Juarez, M.; Basarab, J.A.; Baron, V.S.; Turner, T.; Yang, X.; Aldai, N.; Aalhus, J.L. Influence of alpha-tocopherol supplementation on trans-18:1 and conjugated linoleic acid profiles in beef from steers fed a barley-based diet. Animal 2012, 6, 1888-1896. [CrossRef]

27. Marzocchi, S.; Pasini, F.; Baldinelli, C.; Caboni, M.F. Value-addition of beef meat by-products: Lipid characterization by chromatographic techniques. J. Oleo Sci. 2018, 67, 143-150. [CrossRef]

28. Daley, C.A.; Abbott, A.; Doyle, P.S.; Nader, G.A.; Larson, S. A review of fatty acid profiles and antioxidant content in grass-fed and grain-fed beef. Nutr. J. 2010, 9, 10. [CrossRef]

29. AOAC International. Official Methods of Analysis. 2002. Available online: http:/ /www.aoac.org/ (accessed on 14 December 2020).

30. Lowry, O.H.; Rosebrough, N.J.; Farr, A.L.; Randall, R.J. Protein measurement with the Folin phenol reagent. J. Biol. Chem. 1951, 193, 265-275. [CrossRef]

31. Christie, W.W. A simple procedure for rapid transmethylation of glycerolipids and cholesteryl esters. J. Lipid Res. 1982, 23, 1072-1075. [CrossRef]

32. Verardo, V.; Gomez-Caravaca, A.M.; Gori, A.; Losi, G.; Caboni, M.F. Bioactive lipids in the butter production chain from Parmigiano Reggiano cheese area. J. Sci. Food Agr. 2013, 93, 3625-3633. [CrossRef]

33. Ferri, M.; Gianotti, A.; Tassoni, A. Optimisation of assay conditions for the determination of antioxidant capacity and polyphenols in cereal food components. J. Food Compos. Anal. 2013, 30, 94-101. [CrossRef]

34. Rai, A.K.; Nived, C.; Sakhare, P.Z.; Suresh, P.V.; Bhaskar, N.; Mahendrakar, N.S. Optimization of acid hydrolysis conditions of delimed tannery fleshings by response surface method. J. Sci. Ind. Res. India 2009, 68, 967-974.

35. Bhaskar, N.; Sakhare, P.Z.; Suresh, P.V.; Gowda, L.R.; Mahendrakar, N.S. Biostabilization and preparation of protein hydrolysates from delimed leather fleshings. J. Sci. Ind. Res. India 2007, 66, 1054-1063.

36. USDA-United States Department of Agriculture. Agricultural Research Service, National Nutrient Database for Standard Reference Legacy. Available online: https:/ /fdc.nal.usda.gov (accessed on 14 December 2020).

37. White, J.S.; White, D.C. Source Book of Enzymes, 1st ed.; CRC Press: Boca Raton, FL, USA, 1997.

38. Olsen, J.V.; Ong, S.E.; Mann, M. Trypsin cleaves exclusively C-terminal to arginine and lysine residues. Mol. Cell Proteom. 2004, 3, 608-614. [CrossRef]

39. Haslaniza, H.; Maskat, M.Y.; Aida, W.M.W.; Mamot, S.; Saadiah, I. Optimization of enzymatic hydrolysis of cockle (Anadara Granosa) meat wash water precipitate for the development of seafood flavor. Int. Food Res. J. 2013, 20, 3053-3059.

40. Ryder, K.; Bekhit, A.E.D.; McConnell, M.; Carne, A. Towards generation of bioactive peptides from meat industry waste proteins: Generation of peptides using commercial microbial proteases. Food Chem. 2016, 208, 42-50. [CrossRef]

41. Choi, J.S.; Moon, H.E.; Roh, M.K.; Ha, V.M.; Lee, B.B.; Cho, K.K.; Choi, I.S. Physiological properties of Scomber japonicus meat hydrolysate prepared by subcritical water hydrolysis. J. Environ. Biol. 2016, 37, 57-63.

42. Baggio, S.R.; Bragagnolo, N. The effect of heat treatment on the cholesterol oxides, cholesterol, total lipid and fatty acid contents of processed meat products. Food Chem. 2006, 95, 611-619. [CrossRef]

43. Muchenje, V.; Hugo, A.; Dzama, K.; Chimonyo, M.; Strydom, P.E.; Raats, J.G. Cholesterol levels and fatty acid profiles of beef from three cattle breeds raised on natural pasture. J. Food Compos. Anal. 2009, 22, 354-358. [CrossRef]

44. Brugiapaglia, A.; Lussiana, C.; Destefanis, G. Fatty acid profile and cholesterol content of beef at retail of Piemontese, Limousin and Friesian breeds. Meat Sci. 2014, 96, 568-573. [CrossRef] [PubMed] 